\title{
食酢醸造微生物学の進歩 $(1)$
}

調味料として古い歴史をもつ食酢の生産に関与する醸造微生物について，本稿では酢酸菌を中心に最近十年前 後の研究の進歩に重点をおいて解説していただいた。前号までの清酒に関する微生物学についての解説同様, 釀 造微生物学の進歩を正しく理解する手掛りになるものである。

\section{1.はじめに}

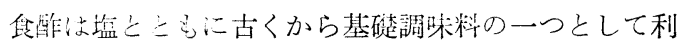
用されてきた。ハスッールが，食䣷が微生物の㗢きでで

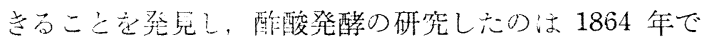
今からう度 120 年前であった。それ以来, 酶酸菌の研究 はいろんな国の多くの人達によって行方机てきた。酢酸

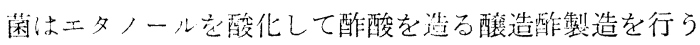
以外に，Dーソルビトールをソルボースに酸化するソルボ 一ス発酵が産業上重要な発酵として役立っている。

驺和 54 年 6 月 8 日告示さ扎た「食酢の日本晨林規

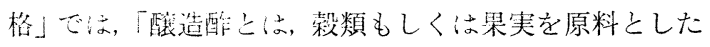
もる及、また济これらにアルコールもしくは糖類を加え

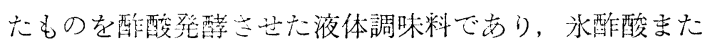
は酰酸を使用しない田のと規定されておりここでい うもろみと:は, アルニール発酵の終っだ清酒, ビール, ブドウ酒等のもる更のことで, これらの製造のためには 梦菌地酵母等の微星物が必要である。これらの微生物に ついて仗念酟之ーカー以外に, 清酒、ビール, ウィスキ 一、ブドウ酒等の各種酒類メーカー的関連研究機関の研 究がはるかに進えでいるため，本稿ではふふれないことに し，主に县酰锤造に必須の酢酸菌之醀酸発酵過程で関連 している酢酸菌以外の微生物について,この十年前後の 研究な中心に涪べる。

\section{2. 酢酸菌の分類}

酶酸菌法ブラム㓌性の絶対好父性桿菌で、ニタノール を酸化して酷酸を生成する細菌の総称である。Bergey's Manual 籍 8版 (1974) ${ }^{1)}$ の分類では, 軲毛を有する場合 は周鞭毛であり、エタノールを酸化して生じた酢酸をさ らに完全に分解する能力の古る Acetobacter 属と莄毛を

\section{正井博 之}

有する場合は極鞭毛で，酢酸分解能を持たないGluconobacter 属の 2 属が設けられている。Acetobacter 属は さらに A. aceti ( 4 覀種) A. pasteurianus ( 5 西種), $A$. peroxydans の 3 種, Gluconobacter 属は, G. oxydams （4覀種）の 1 種に分類されて拈り，第 1 表に示したよ らに配置されている。

第1表 Bergey's Manual 第8版に打ける酶酸菌 の配置

PART 7.

GRAM-NEGATIVE AEROBIC RODR AND COCCI

Family I. Pseudomonadaceae

Genus IV. Gluconobacter

Species 1. Gulconobacter oxydans

Subspecies 1a. Gluconobacter oxydans subsp. oxydans

Subspecies $1 \mathrm{~b}$. Gluconobacter orydans subsp. industrius

Subspecies 1 c. Gluconobacter oxydans subsp. suboxvdans

Subspecies 1d. Gluconobacter oxydans subsp. melanogenes

Genus of Uncertain Affiliation

Genus Acetobacter

Species 1. Acetobacter aceti

Subspecies 1 a. Acetobacter aceti subsp. aceti

Subspecies $1 \mathrm{~b}$. Acetobacter aceti subsp. orleanensis

Subspecies 1c. Aectobacter aceti subsp. xylinum Subspecies $1 \mathrm{~d}$. Aectobacter aceti subsp. liquefaciens

Species 2. Acetobacter pasteurjanus

Subspecies 2 a. Acetobacter pasteitrianus subps. pasteurianus

Subspecies $2 \mathrm{~b}$. Acetobacter pasteurianus subsp. lovaniensis

Subspecies 2c. Acetobacter pasteurianus subsp. estunensis

Subspecies 2d. Acetobacter pasteurianus subsp. ascendens

Subspecies 2 e. Acetobacter pasteurianus subsp. paradoxus

Species 3. Aectobacter peroxydans 
その後, 1975 年, 飴山礼にり，G. oxydamsの新しい 亜種として G. oxydams subsp. sphaericus が記載され, また, 1980 年, SwInGs ${ }^{3)}$ らにより Frateuria という新 属が提晿されたが，これらは古く，1958 年近藤，滄山神 により A. aurantium として記載されたものであり, 酷 酸菌のカテゴリーに入るものである。

また, 最近, Bergey's Manual 第 8 版の分類体系の見 直しを提唱する報告が，Gillis $5^{5)}$, Gosselé $ら^{6,7)}$, 山 田 ${ }^{9,10)}$, によりあいついで出されているので以下に紹

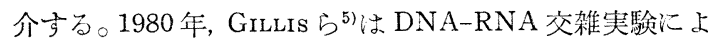
り, Acetobacter 属を Acetobacteriaceae 科比含させる こと起提唱した。その後 1983 年, GOSSELÉS ら ${ }^{6)}$ は数理分 類およびタンパク質の電気泳動パターンに用いた分類学 的研究により,Gluconobacter些を亚種にすることは妥当 性に欠け，Gluconobacter oxydans 1 種に分類すべきで あると提唱している。同じくGosseLÉ らはAcetobacter 属に関しても同様の分類学的研究を行ない, Acetobacter 属を, A.liquefaciens, A.hansenii, A. aceti, A.pasteurianus の 4 種に再分類することを提晿している。な 出, 1979 年, LoITSIANSKAYA $ら^{8)}$ は, 同様に数理分類に より, Gluconobacter 属注, G. oxydans $の 1$ 種, Acetobacter 属は, A. aceti (A. aceti subsp. aceti), A. rancens (A.pasteurianus subsp. pasteurians), A.xylinum ( $A$. aceti subsp. xylinum) の 3 種に分類できることを報告し たが, この研究では, A. aceti subsp. liquefaieris, A. pasteurians subsp. estunensis, A. pasteurianus subsp. paradoxans, A.peroxydans は含まれていなかった。ま た, 山田ら゙はユビキノン系, 酵素の電気泳動パターン, DNA-DNA 交雑を用いた分類学的研究により，A. aceti subsp. liquefaciens 学 A. liquefaciens として種に昇格さ せること, 同じく山田 ${ }^{101}$ は A. aceti subsp. xylinum を A. xylinum として種に昇格させることを提唱している。

これらの研究者の努力により釄酸菌の新しい分類体系 が確立されつつあるが，まだ十分とはいえない。たとえ ばG. oxydansやA. pasteurianusのDNAのGC含量が 各々 $56 \sim 64 \%{ }^{6)}, 53 \sim 63 \%{ }^{7)}$ と現在の分類学的背景から みて 1 種に分類するにはその幅が広すぎるなどの問題点 も㐫り，酢酸菌の分類には今後に残された課題む多い。

\section{3. 食酢䁔造に適した酢酸菌}

食酰製造法の型式は表面登酵法と深部発酵法に大别さ

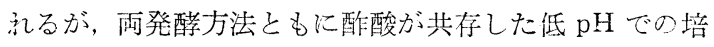
養環境であり，他の発䤃産業とはかなり異った環境下で 進展してきた。即ち, 数々の酢酸菌が同一の登醳槽で共 存しながら，その環境に適会したものが生さ残り，自然 淘汰を受けて，夫々の立場の覔秀菌として引学継がれて
第 2 表 䣷酸菌の梁篗源に関する研究りス卜

\begin{tabular}{|c|c|c|}
\hline 研㠾者 & 䅦 & 栄寒物 豆 \\
\hline UNDERKOFLER ${ }^{12}$ & A. suboxydans & 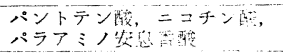 \\
\hline $\begin{array}{l}\text { FoDA } \\
\text { RAO }^{14)}\end{array}$ & A. melanogenum & $\begin{array}{l}\text { 同 上 } \\
\text { 他にサイアミン }\end{array}$ \\
\hline 飴 $\uplus^{15)}$ & $\begin{array}{l}\text { Actobacter 屈 } \\
\text { Gluconobacter 尿 }\end{array}$ & $\begin{array}{l}\text { ビタミン婴求性なし } \\
\text { パントテン酸 }\end{array}$ \\
\hline STOCKESi€ & A. suboxydams & アミノ酸哭求性 \\
\hline BELLY ${ }^{17)}$ & A. suboxydans & $\begin{array}{l}\text { グルタミン酸, ダルタミン } \\
\alpha-\text { タグルタル酸 } \\
\text { プロリン, ヒスチジン }\end{array}$ \\
\hline 相 $[18)$ & Acctubacter & $\begin{array}{l}\text { プスパシギン酸, ッルタミン } \\
\text { 酸 } \\
\text { プロリン, アラニン }\end{array}$ \\
\hline 土市 19,202 & A. rancens & 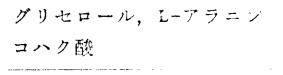 \\
\hline+212 & acetocbter & 味喽湭油 \\
\hline 塄22) & 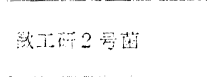 & $\begin{array}{l}\text { 味喗, 留油 } \\
\text { 白琵油 }\end{array}$ \\
\hline$f^{23}$ & $\begin{array}{l}\text { A.ranclus } \\
\text { G. suboxydance }\end{array}$ & 麦 恨 \\
\hline
\end{tabular}

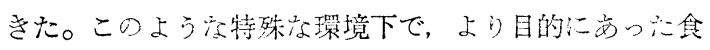
酶製造を指向し，種々の研究が長年行われてきだ。

ここで法，酷酸菌の能力向上を目指して行っ忐，種々 の研究を以下の四項目別に分けて述べることとする。

\section{1 栄養源, 発酵促進物質等に関する研究}

酶酸菌汇閔する研究は非常に古くから多岐にかたって

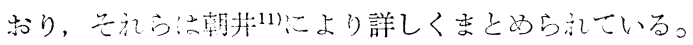
食酶製造現場で怘，眽酸菌の中でも非常に好氛的でしか 马高い酸度のもとで高濃度のアルコールを效䓋よく酢酸 に変えるここのだきる菌が求められている。培地の面で

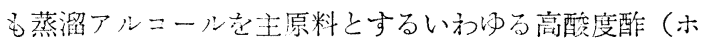
ワイトビネガー）以外永, アルコールの他に嵌素源, 窒 素源及び無機塩類等をわなり多量に含む原料を使用与る 場合が多、。しふぶって食䝫製造業者の関心の一つは, 現在使用中の培地に不足していて, 微量の添加で発酵学 促進してくえるもの斿ないかといらことである。したが ってビタミン類，アミノ酸類及び酵母エキス等に含志れ る徽量の栄盖素に古くから関心がもたれて種々の研管が

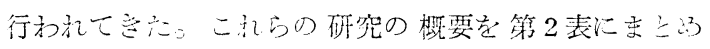

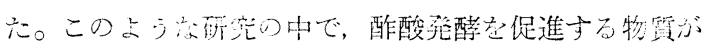

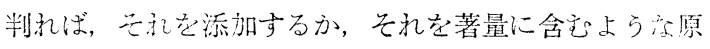
料を使用するこしにより安定した高能率な登醉をささる ことが可能で方り，この面での研究に等せる期待は非箈 に大きい。

\section{2 純粋培養に対する研究}

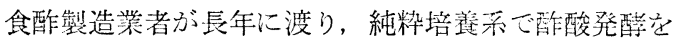
行ってこなかったの!酒酸発酵が他の発酵食品工業之 
巽り極端に二低い $\mathrm{pH}$ 条件で発酵を終始完結するため,一 般の微生物の污染を受ける危険性が非常に少なかったこ とが最大の理由である。かりに純粋菌で発酵を行らため に，無菌設備に 2 倍近くの投資経費をかけ，あらゆる設 備を殺菌するために，消費エネルギーに経済的負担をか けてもそれに見合らメリットがなかったことにもよる。

紊た, 第 2 の理由として, 主要発酵菌以外の従属微生 物が生産する酢酸以外の微少に生産する生産物が, 醸造 酢としての, 特徵的風味に寄与する部分が大きいため, あくまでも主要発醉菌を培䔃技術的でカバーしながら他 の従属菌の混在下で発酵を行ら混在培養系に依存せざる を得なからた訳でもある。

しかしながら， SHIMWELL24)はこのよらな状態を脱却 しないこ上には，他の発酵産籍との格差が，ますます生 じると指摘し，A.mesoxydans を用いて，木綿をつめた 喜さ $5>$ フートのガラス管を用いて種々の発酵法でモル ト酶, アルコール酢及びブドウ䣫の純粋培養による食酢 製造実験を行って，好結果を得たことを報告している。 SUOMALAINEN ら 251 尤ば, フィンランドにおいていわ 预どネレーターでの連続法でアルニール酢を造るの に, 20 年間純粋培盖が用いられていると述べている。実 験室規模での深部培荃試験は, A. acetigenusを使った LOPÉZ ら ${ }^{26)}$ Kよって, また A. aceti 党使って, Alian ら 27,281 にって行われている。

我国でも飯㴊ら ${ }^{29}$ は, 酶酸菌つ type culture 43 株及び 種酢 95 点から酢酸生成速度の大きい菌 6 株を選択して 食酸醉造業者の使用に供している。純粋分離した菌を混 合して使用することについては, Hromatka ら ${ }^{301}$ や飯㴊

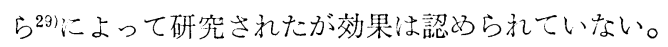

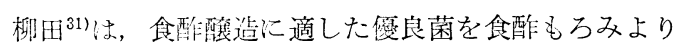
分離し, A. aceti type 4 種, A.rancens type 2 種の菌が 優良であるとして，公の諎性質を調べている。Young ら 321 は, クローバーの花の䣫から, 数種の酥酸菌を分離 し, その生理学的性質を検討し, 食酷醸造への適用性に

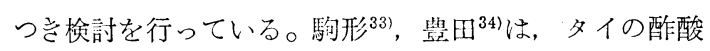
菌を分離し，その諧性質につき検討している。

この上うに, 多くの試みや研究がなされているが, 純 糊培盖での工業化涼皆無に近いのがその実態である。し かしながら，将来の最も早い時期に純粋培盖系の確立さ れる分野は, 高酸ホワイトビネガーの製造部門であると 思われる。

\section{3 菌株の分離と保存}

\section{3-3-1 分離}

酷酸菌は, 古く, 1873 年に KutZING ${ }^{35)}$ により, 酹化 したビールやワインから微生物の一種として認知され て以来, 食酢 (種䣫)、ビール，ワイン等を中心とした分
離源より多数分離されている。この中には食酢製造上有 用な菌株が含まれており，その多くはA. cetobacter 属 の酢酸菌で㐫る。一方 Glucono bacter 属や Frateuria 属の酶酸菌はその多くが，バナナ，イチゴ，カキ, ニリ， キイチゴ等の植物から分離されたものであり一部の例外 を除き，食酷製造に直接関連したものは少ない。

食酷製造の優良菌は通常, 酵母エキス，ペプトン，モ ルトエキス, グルコース等からなる基礎培地にエタノー ル, 炭酸カルシウムや酢酸を添加した寒天平板培地で分 離されているが，ここで分離されるのは表面発酵法や， 酢酸酸度が $10 \%$ 以下の中酸度深部発醳法の優良菌であ り酢酸酸度が $10 \%$ 以上の高酸度深部発酵法の優良菌は 通常の寒天平板培地では分離できない。しかし筆者ら ${ }^{36)}$ は最近酵母エキス，ペプトン，グルコースおよび瞃酸 $6.5 \%$, エタノール $2 \%$, 寒天 $0.5 \%$ からなる軟寒天培 地上に寒天を $1 \%$ とした同培地を薄く重層した寒天平 板培地を用い，加温培養することにより，20\%以上るの 高酸度酢を製造できる優良菌を分離することに成功し た。

3-3-2 保存

酶酸菌の保存は，一般には炭酸カルシウムを源加した 粚浸出液寒天培地や酵母エキス，ペプトン，グルコー ス, エタノールからなる酶酸菌用寒天培地飞培盖し， 5 ${ }^{\circ} \mathrm{C}$ にて冷蔵保存し，1か月毎に植え継ぎをすればよい。 しかし、この方法では酶酸発酔能, 眽酸耐性などの重要 な性質が劣化することが多く実用面からみて好ましいも ので法ない。継代培養保存の場合でも培地適量のエタ ノールと酶酸を添加して打けば, ある程度酶酸発醅能や 酢酸耐性は保持されることがわかっている。しかし，完 全に 保存することが困難なため，長期にわたり菌株の 性質を安定して保存するには凍結乾燥保存や谏結保存 $\left(-80^{\circ} \mathrm{C}\right)$ が好ましい。年の具体的方法は SoÜREK ら ${ }^{377}$ K よって示されて就り, NICKOL ら ${ }^{381}$ 牲谏結乾燥菌株を使 用して深部発酵法（直接バッチシステム）での食酢の製

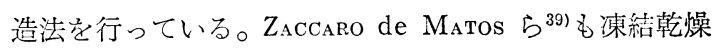
し 1 年間保存した後, 数種の酥酸菌について発醅状態を 観察しその変化のなかったことを確かめている。筆者ら も過去 20 年あまり, 凍結乾燥法により有用酷酸菌の保 存を行っているが, その間, 增殖能, 酶酸発酵能, 酢酸 耐性などの性質になんら変化を認めて招らず，その有効 性を確認している。この場合の方法としては, スキムミ ルク，シュークロース, グルタミン酸ナトリウムからな る一般的な分散媒に菌体を懸濁し, 常法通り凍結乾燥を 行えばよい。凍結乾燥菌株は冷蔵保存しておき必要に応 じて復水して使用している。また同上の分散媒を用いた 凍結保存法も簡便であり, 保存性も高く良い方法とい兄 


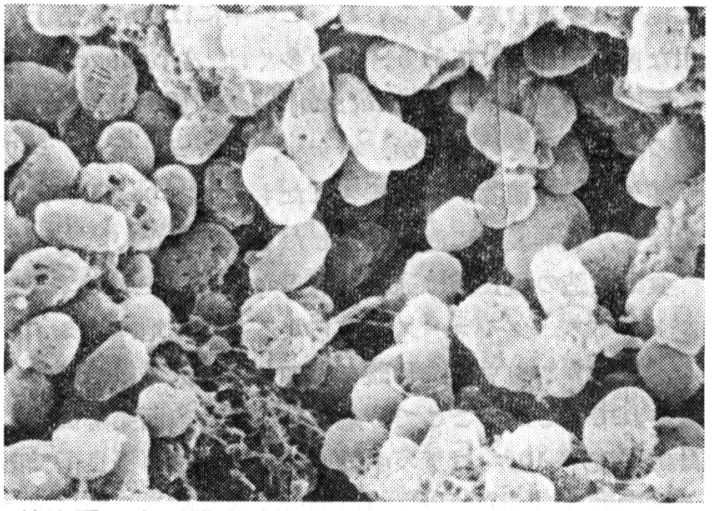

第 1 図表面酸酵に使用されている酢酸菌（俗称チリ メン菌）の走査型電子影微鏡写真 $(\times 10,000)$

よう。

\section{4 優良酢酸菌の性質}

工業的な食酢製造に捻いてい，純粋酢酸菌を用いるこ とは稀であり，いわゆる前回に良好な発酵成積を示した 食酢醪を種酢として繰り返し使用する混合培責を行って いるのが実態である。したがって長年の醸造過程で馴養 淘汰された酢酸菌が主要発酵菌となっている。主要発酵 菌は発酵原料や発酵方法により異って来ており, その実 態は複雑であるが, なかでも後者の影響が大きく, 表面 発酵之, 酢酸濃度が 5 10\%の中酸度深部発酵や, 10〜 $20 \%$ の高酸度深部発酵では明らかに異った酢酸菌が主 体をなしている。

これら 3 発酵法での優良菌を分離し, それらの性質を 十分認知しておくことは, 酢酸発酵の安定化苍図るため の 1 手段としての純粋培養による製造や, 後述する遺伝 子操作等で酢酸菌の育種改良を進めていく上での絶対必 須条件となる。筆者らは, 我社の工場の中で, 優良菌と 認知している酢酸菌の分類学的検討を Bergey's Manual 第 8 版及び最近の研究を参考にして行ってきたが, こ こでは, 表面発酵法, 中酸度深部発酵法, 高酸度深部発 酵での優良菌及び高温耐性菌について述べる。

\section{4.1 表面発酵酢酸菌}

表面発酵の主要発酵菌は, 俗に“チリメン菌”之呼ん でおう，その名の通り綟布のチリメンのよらな美しい光 沢と特有のシワを持った菌膜を形成する。この菌膜は液 面にしっかりと特有の粘着性と伸張性を持って保持され て和り, 全発酵期間中液面に強固に保持, 浮遊しながら 発酵を完結する。第 1 図は表面発酵の菌であるが各菌体 が粘質様のもので抒㐨われてい。

表面発酵での優良酢酸菌の具備すべき性質として, 次 のような性質が必要であると考えられる。

1. 菌膜のはりの速く, 光沢のある絹布状またはらり めん状の膜でしかも弾力性のある菌膜を形成する

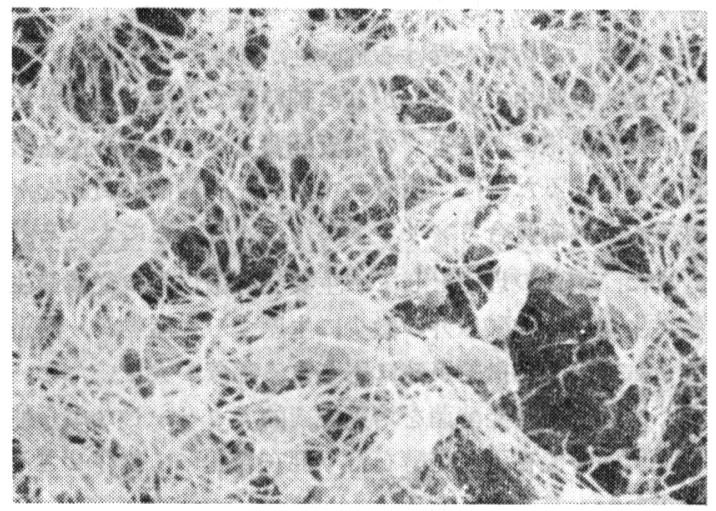

第 2 圈 A. aceti subsp. xylinum (俗称コンニャ》 菌) の走查型電子顕微鏡写真 $(\times 10,000)$

छの

2. 菌膜の老化は速くなく，培養の末期まで健全な皮 膜老保持するもの

3. 酸の生成の開始が速く, その後の酸生成速度が発 酵末期まで劣えず，直線的に進むもの

4. 菌膜を移植した場合再び菌膜を速やかに形成する \&䧑

5. 日的の酸濃度丈で上げうる酸化能力があるもの

6. 出来た酢酸を分解しないるの

7. 残留アルニールのある限り発酵を続け途中で終っ たりすることのないもの

8. 出来た酢の香りがさわやかな芳香を有するもの

9. 天然の培地によく繁殖し，酢の生産を円滑に進め るもの

10. 酢からの菌の分離が容易なもの

11、出来た酢は, 混濁していないで, 沪過, 精製が容 易な子の

以上の条件をすべて，充足することは出来ないが汪 ぼ満足できる菌体が分離されており，A.pasteurianus subsp. pasteurianus 之同定 ${ }^{36) さ れ て い る 。 ~}$

な执, A. aceti subsp. aceti や A. aceti subsp. xylinum も食酢表面発酵醪から分離同定されているが, 前者の多 くは, 菌膜がもろく, 発酵液を混濁させ, 菌体の除去性 に問題があり, 後者は古くから, 有害酢酸菌として知ら れている厚膜形成菌である。この厚膜はセルロースであ り, 走查型電子顕徽鏡では, 第 2 図のように菌体に緎維 状にから来った状態が観察される。A. aceti subsp. xylinum は通称 “コンニャク菌”之呼ばれているものであ り，酶酸発酔中に污染されると生産速度の低下をさた す。また熟成貯蔵中に污染されると酢酸が 分解され, 過酸化臭と呼ばれる異臭が発生する。過酸化臭の成分と してイソ酪酸, イソ吉草酸, プロピオン酸が知られて㧤 りエチルアルコール, 酢酸エチルの減少もその要因とな 
っている ${ }^{40,41) 。 ~}$

\section{4 .2 中酸度深部発酵菌}

酢酸濃度が $5 \sim 10 \%$ の中酸度深部発酵での優良菌と しては, 生酸速度が高く, 菌体の除去性が良く, 香味の 良いといら 3 点を少なくとも具備している必要がある。 筆者ら ${ }^{36}$ は, これらの条件を及たしている眽酸菌を分離 乙同定試験を行った。その結果, 分離菌はセルロース形 成能がない点及びその他若干の性質を除くと，A. aceti subsp. xylinum とその性質が一致し, 深部発酵を繰り返 すことにより, A. aceti subsp. xylinum のセルロース生 成能欠損株が主体をなすようになったものと思われる。 従来不良酢酸菌とされている A. aceti subsp. xylinum が中酸度深部発酵での主要酢酸菌となっていることは, 馴養といら観点からみて興味深い現象とい方よう。

\section{4 .3 高酸度深部発酵菌}

䣷酸酸度 $10 \%$ 以上，時には $20 \%$ 以上の高酸度深部 発酵での優良菌は通常の酢酸菌用寒天平板培地上では生 育せずその分離が困難であったが，3-3-1 で述べたよう な特殊な軟寒天培地を用いて，加湿培養することにより 分離することができた。ここで得られた分離菌は既知の 酢酸菌や前述の A. aceti subsp. xylinum とも生理学的 性質に打いて明らかに異っていた。また，菌体脂肪組 成, ユビキノンシステム, DNA の GC 含量, DNA 相 同性等の化学分類学的検討結果からも既知の酢酸菌とは 明白に区別できた。これらの結果より，高酸度深部発酵 での優良菌はAcetobacter 属に属する新種であると認め A. altoacetigenes と命名することを提晿したが36), 現在, 正式な発表の準俑を進めているところである。

\subsection{4 高温耐性酢酸菌}

1973 年の石油ショックを引き金として省エネルギー 対策は, 各企業のターゲットとなってきている。食酰製 造も例外ではない。たと党ば深部酢酸発酵では, 通常の 発酵温度で山る $30^{\circ} \mathrm{C}$ を $37^{\circ} \mathrm{C}$ まで高めることが可能に なると，その泠却費は $1 / 2$ に削減できる。しかしながら $35^{\circ} \mathrm{C}$ 以上で実用レベルの生産能をもつ菌株は知られて いなかった。このため, 土裹, 果実, 食酢醪から多くの 酢酸菌を分離し（1, 184 株） $35^{\circ} \mathrm{C}$ 以上ですぐれた発酵能 をもつ数株を選択した。これらの高温耐性菌の起源はす べての表面発酵醪から分離されたものであり，この発酵 方法では発酵の最盛期に液温が $40^{\circ} \mathrm{C}$ 近くまで上昇する ことを考えると興味深いことである。分離菌のらち, 最 も温度耐性が高く, $35^{\circ} \mathrm{C}$ では $30^{\circ} \mathrm{C}$ と全く変わらぬ生産 能を示した菌株は A. aceti subsp. aceti と同定された

(つづく)

(中埜生化学研究所)

\section{文献}

1) J. De Ley, J. Frateur : In Bergey's Manual of Determinative Bacteriology, 8 th Ed., ed. by R. E. Buchaman, N.E. Gibbons, : The Williams \& Wilkins Co., Baltomove p. 251276 (1974)

2) M. Амеуама : Int. J. Syst. Bacteriol., 25 (4) 365 (1975)

3) J. Sivings, M. Gillis, K. Kersters, P. De Vos, F. Gosselé, J. De Ley, : Int. J. Syst. Bacteriol., 30 (3) 547 (1980)

4) K. Kando, M. Ameyama : Bull. Agric. Chem. Soc. Jpn., 22369 (1958)

5) M. Gills, J. De Ley : Int. J. Syst. Bacteriol., 30 (1) 7 (1980)

6) F. Gosselé, J. Swings, K. Kersters, J. De LEY : Int. J. Syst. Bacteriol., 33 (1) 65 (1983)

7) F. Gosselé, J.Swings, K. Kersters, P. Pauwels, J. De Ley : System. Appl. Microbiol., 4 338 (1983)

8) M. S. Loitsianskaya, G. V. Pavlenko, A. I. IvCHENko: Mikrobiologiya, 48545 (1979)

9) Y. Yamada, M. Акita, T. Koda, Y. Tahara, H. Yoshioka: J. Gen. Appl. Microbiol., 29327 (1983)

10) Y. YAMADa : J. Gen. Appl. Microbiol., 29417 (1983)

11) T.Asai : "Acetic Acid Bacteria" Univ. of Tokyo Press, Tokyo (1968)

12) L. A. Underkofler, A. C. Bantz, W. H. Peterson: J. Bacteriol., 45183 (1943)

13) I. O. Foda, R. H. Vaughin : J. Bacteriol., 6579 (1953)

14) M. R. R. RaO, J.L. Sтокеs: J. Bacteriol., 65 405 (1952)

15) M. Ameyama, K. Kondo: Agric. Biol. Chem., 30 203 (1966)

16) J. L. Stokes, A. Larsen: J. Bacteriol., 49495 (1945)

17) R. T. Belley, G. W. Claus: Arch. Mikrobiol., 83237 (1972)

18）柳田藤治, 山本 泰, 西島英雄, 住江金之：醸協 69 (8) 517 (1974)

19）土方康世，照井堯造：醱工 $50 \quad 7$ (1972)

20) 土方康世：特公昭 50-4760

21）川村吉也：特公昭 47-26720

22）南場 毅, 竹内徳男: 日本食品工業学会 第 24 回大会研究発表要旨 p.15 (1977)

23）照井堯造, 土方康世, 奥村 一：特公昭 49-15798

24) J. L. Shimwell : J. Inst. Brew., 60136 (1954)

25) H. Suomalainen, A. J. A. Ker Änen, J. Kangasperko: J. Inst. Brew., 7141 (1965)

26) A. Lopez, L. W. Johnson, C. B. Wood: Appl. Microbiol, 9425 (1961)

27) A. Alian : Mikrobiologiya, 36738 (1963)

28) A. Alian, I. L. Rabotnova : Mikrobiologiya, 33 
631 (1964)

29）飯㴊貞明, 服部 堯: 䣨協 28398 (1970)

30) O. Hromatka, U. Leutner: Die Branntweinwirtschaft, 103114 (1963)

31）柳田藤治：醸協 73 (6) 436 (1978)

32) Hee Cheon Yang, Dong Sung Choi : J. korea Agúcultural Chmical society 22150 (1979)

33）駒形和男：私信 (1980)

34）豊田 泰, 山崎道雄 : 昭和56年度農化大会講演要 旨集 p. 62 (1981)

35) F. T. Kützing: J. prakt. Chem. 11385 (1837)

36）円谷悦造, 大森昭治, 藤山清一, 正井博之, 鈴木 健一朗, 昭和 59 年度農化大会講演要旨集, p. 398 (1984)
37) J. Soürek, M. KulHÁNek : Zentralblatt für Bakteriologie, Parasitenkunde, Infektionskrankheitenund Hygiene, 123581 (1969)

38) C. B. Nickol, H. A. Conner, M. Dukowicz, F. M. Hildebrant : Vineger News Letter No. 43 (1964)

39) C. Z ACCaro de Matos, T. C. Forah : Rev. Lact, arner, Microbiol, 1321 (1971)

40) G. Yamaguchi, H. Masai : Agr. Biol. Chem., 391907 (1975)

41）正井博之, 円谷悦造：日本醱酵工学会 昭和 58 年 度大会講演要旨集, p. 31 (1983)

42) S. Ohmori, H. Masai, K. Arima, T. Beppu : Agr. Biol. Chem., 442901 (1980)

\section{蒸しと麥匊のコンサルタント}

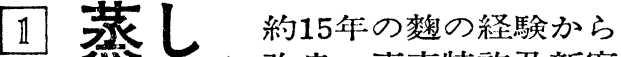
改良・尃売特許及新案

約 8 件・コシキ理論を忠実に改良 二望こしき（断熱材使用）

横式連続蒸惹装置
2 麥匊各地名酾家でご採用

$3 \sim 5$ 段

薄盛式自動製麴機

株式会社

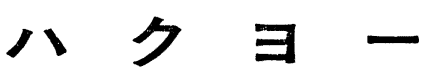

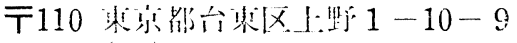
TEL (03) $833-8940$ 